\title{
A TEMPORAL PROFILE OF PRO-ABSTINENCE-ORIENTED CONSTRUCTS FROM THE MODIFIED THEORY OF PLANED BEHAVIOR IN A SLOVENIAN CLINICAL SAMPLE OF TREATED ALCOHOLICS - AN 18-YEAR FOLLOW-UP ČASOVNI PROFIL KONSTRUKTOV PRILAGOJENE TEORIJE NAČRTOVANEGA VEDENJA V SLOVENSKEM VZORCU PACIENTOV PO ZDRAVLJENJU ODVISNOSTI OD ALKOHOLA - 18-LETNO SLEDENJE
}

\author{
Mirjana RADOVANOVIĆ ${ }^{* *}$, Maja RUS-MAKOVEC ${ }^{1}$
}

${ }^{1}$ University Psychiatric Hospital Ljubljana, Alcoholism Treatment Unit, Poljanski nasip 58, 1000 Ljubljana, Slovenia

\section{ABSTRACT}

Keywords:

long-term abstinence, behavioral indicators, theory of planned behaviour, alcoholism treatment

\section{IZVLEČEK}

Ključne besede: dolgoročna abstinenca, kazalniki vedenja, teorija načrtovanega vedenja, program zdravljenja sindroma odvisnosti od alkohola
Introduction: Using the modified Theory of Planned Behaviour (mTPB), different indicators of therapeutic success were studied to understand pro-abstinence behavioural orientation during an 18-year after-care period following a 3-month intensive alcoholism treatment. The indicators were: perceived needs satisfaction (NS), normative differential (ND), perceived alcohol utility (UT), beliefs about treatment programme benefits (BE) and behavioural intentions $(\mathrm{BI})$.

Methods: The sample of 167 patients who consecutively started an intensive alcoholism treatment programme has been followed-up for 18 years, using standardised ailed instruments at the end of the treatment, and in the years 4-5, 9 and 18 of follow-up. The last data collection was completed by 32 subjects in 2010. The analysis followed the standard explore-analyse-explore approach. After the initial descriptive exploration of data, multivariate analysis of variance (MANOVA) in SPSS statistical package was set to explore between-groups and within-groups differences over time.

Results: At the between-group level, $\mathrm{BI}$ remained stable at the same level as at the end of the treatment programme, whereas BE and UT robustly changed over time and levelled off after 10 years of follow-up. NS and ND show a trend of pro-abstinent orientation and level off after 10 years of follow-up, although the trend is not significant. The same results were confirmed by the within-subject level.

Conclusions: Studied constructs stabilised after ten years of follow-up, apart from BI. The latter suggests that $\mathrm{Bl}$ level needed for completion of an intensive treatment programme suffices for the maintenance of abstinence when accompanied by the change in perception of alcohol usefulness.

Uvod: Z uporabo konstruktov iz prilagojene Teorije načrtovanega vedenja smo raziskovali kazalnike terapevtskega uspeha po intenzivnem zdravljenju sindroma odvisnosti od alkohola in $v$ obdobju 18-letnega sledenja, da bi bolje razumeli v abstinenco usmerjeno vedenje skozi čas. Uporabljeni kazalniki so: subjektivna zaznava zadovoljitve potreb (NS), normativnost (ND), subjektivna zaznava privlačnosti alkohola (UT), prepričanja o koristnosti programa zdravljenja (BE) in vedenjski nameni (BI).

Metode: Vzorcu 167 pacientov (128 moških in 38 žensk), ki so zaporedno vstopili v program intenzivnega zdravljenja sindroma odvisnosti od alkohola, smo sledili 18 let. Podatke smo zbirali ob koncu programa zdravljenja ter pet, deset in osemnajst let po končanem programu. Standardne vprašalnike smo anketirancem poslali po pošti. Na zadnji vprašalnik je odgovorilo 32 oseb (26 moških in 6 žensk). Obdelava podatkov je upoštevala uveljavljen tristopenjski pristop deskripcija - analiza - raziskava. Razlike v kazalnikih skozi čas smo analizirali z metodo multivariatne analize variance (MANOVA). Uporabljeni statistični paket je bil SPSS.

Rezultati: Analiza razlik skozi čas (raven med skupinami) je pokazala, da je BI na enaki ravni ves čas sledenja kot po končanem zdravljenju, medtem ko sta se BE in UT robustno spreminjala $v$ obdobju sledenja in se stabilizirala deset let po končanem zdravljenju. Tudi NS in ND kažeta trend $v$ smeri proabstinenčnega vedenja in stabilizacijo po desetih letih, vendar razlike niso statistično značilne. Analiza razlik na ravni subjektov je potrdila rezultate na ravni populacije.

Zaključki: Proučevani konstrukti so se stabilizirali po desetih letih sledenja, z izjemo BI, ki je bil ves čas študije na enaki ravni kot po zaključenem programu zdravljenja. Iz slednjega je mogoče sklepati, da je raven vedenjskih intenc, $k i$ je potrebna za uspešen zaključek intenzivnega programa zdravljenja SOA, zadostna za vzdrževanje abstinence skozi čas, če temu sledi sprememba $v$ doživljanju privlačnosti alkohola. 


\section{INTRODUCTION}

Behavioural changes are one of the first recognized consequences of the addiction. The same is true for the syndrome of alcohol dependence. They are rather well understood by the patients themselves and people around them. Human beings are biologically equipped to observe, compare and interpret behaviours. Nevertheless, how well do we truly understand the mechanisms behind representations of a vast variety of behaviours? Do we have accepted or agreed upon theoretical concepts explaining the driving forces and many different facets of a behaviour? One of the theories that drew researchers' attention from many scientific fields was developed by Icek Ajzen. His earlier work on the Theory of reasoned action (TRA) was extended in the 1980s to the Theory of planned behaviour (TPB). Briefly, TPB has its roots in the research of the attitudes by Allport and is based on Expectancy value models by Triandis (1). Ajzen, Fishbein and their colleagues set out to explain the discrepancy between the attitudes and observed behaviours, and they named this approach the Theory of reasoned action (1, 2). However, not all behaviour is fully intentional. By adding the concept of perceived behavioural control, their theoretical framework focused on predicting deliberate behaviours, hence the name TPB (3). The core assumptions are: a) a person's behaviour is determined by her/his intention to perform a behaviour of choice; b)this intention is a function of one's attitude(s) toward said behaviour and one's subjective norms about the behaviour in question; c)another key factor is a perceived behavioural control (3). Addiction is a disease which mobilises all the abilities of a patient to sustain itself for as long as possible. Alcohol is the most widely used drug in the world. Epidemiological data from general population and student population studies show time and again that its use is among the highest in Europe (for recent data, see e.g. 4, 5). Addressing the negative or dysfunctional behavioural patterns and helping the patients develop new, health-oriented behaviours are among the more important goals of intensive addiction treatment programmes, alcoholism treatment included. The effectiveness of intensive alcoholism treatment programmes is evidencebased and comparable to treatment outcomes for other chronic non-communicable diseases (6-8). Alcoholism treatment programmes are also economically efficient if the patient remained sober up to 12 months $(7,8)$. On the other hand, to the best of our knowledge, few studies researched prognostic factors for stabile abstinence and long-term benefits (more than five years) of treatment due to complexity of factors influencing the outcomes (911 ), or the studies used very specific populations (e.g. adolescents, young adults, specific co-morbid conditions) (e.g. 12), or were completed more than 30 years ago (13). Even fewer studies were based on behavioural theories, rather than diagnostic criteria, which change over time
$(14,15)$. The modern understanding of treatment effect encompasses a broad concept of rehabilitation at a level of psychosocial functioning (16). The results of rehabilitation are incorporated into a pro-abstinence oriented lifestyle, i.e. relatively unburdened by the addiction-related problems. Such changes promote functional behaviours within the family, work and social environments of the patient, thus reflecting a paradigm shift from 'having a chronic non-communicable disease' to 'being in a state of conditional health', when pro-abstinence lifestyle is sustained over time. Recognition of long-term prognostic factors for abstinence and non-addiction-oriented lifestyle (together underlining 'pro-abstinence behaviours') informs both: for clinical populations, more personalised alcoholism treatment goals, based on individuals' needs; and for alcoholism prevention programmes for general population, a theoretical background aimed at decreasing the burden of the disease.

TPB explains a chosen behaviour (e.g. abstinence from alcohol) as a result of intentions to engage in a behaviour and relevant attitudes towards behaviour, subjective norms and behavioural control (17), similar to Bandura's concept of self-efficacy (18). Clinical experiences based on following-up patients who had completed the intensive treatment programme and abstained from alcohol and other drugs for two or more years yielded an observation that this group of the clinical population accomplished abstinence-oriented behavioural changes, but many of them lacked the ability to feel good or find pleasure in life. Our project used modified TPB model (mTPB) to include perceived needs satisfaction (NS). This concept is based on Maslow's classification of needs and includes acceptance, safety and creativity $(19,20)$.

The aim of this study is to understand the relationship between long-term abstinence ( 5 years after the treatment and onwards) and mTPB constructs over 18-years of follow-up after the intensive hospital-based and abstinence-oriented high threshold alcoholism treatment programme.

\section{SUBJECTS AND METHODS}

The study used a convenience sample of 167 (128 male, 38 female) consecutive patients admittedinto an intensive hospital-based alcoholism treatment programme in 1992. This intensive treatment programme could not admit patients with severe impairment in neuropsychological functioning, acutely suicidal or acutely psychotic patients without long-term stable remission. The programme duration was on average 10-12 weeks. It followed a biopsychosocial paradigm, and was comprised of group psychotherapy and additional treatment modalities (e.g. occupational therapy, art therapy, social skills training, etc.). It had two phases: during the first, patients 
were full-time inpatients and, during the second, they continue the same programme, but spend two-thirds of the day outside of the institution (patients were in a day hospital). An active participation of important others was stressed as an essential part of the programme and the aftercare recovery in a group setting once a week was strongly recommended. Treatment orientation has been based on the synthesis of different therapeutic approaches, including principles of psychodynamic group psychotherapy, behavioural-cognitive interventions, elements of motivational enhancement therapy and (behavioural) marital and family therapy. The sample gender distribution was the same as in the clinical population. Subjects' average age in 1992 was 38 years.

The research was approved by Republicof Slovenia National Medical Ethics Committee and it conforms to the provisions of the Declaration of Helsinki in 1995 (as revised in Edinburgh in 2000). All the study subjects were informed about the details of the study and that the return of the fulfilled questionnaires will have been treated as the acceptance of the informed consent. The refusal to accept the informed consent was the only exclusion criterion.

Mailed standardised self-fulfilled structured instruments were used. The original TPB by Ajzen was appealing to the research team because it did not require a specific questionnaire and it allowed modifications of the constructs. Our modification includes three constructs from the original TPB: normative differential, behavioural intentions and beliefs, and two constructs to include our research subject of interest: alcohol utility and perception of needs satisfaction. The instruments were constructed and standardised via use in different populations. Several kinds of validity were considered. Contrast or opponent groups validity was tested in representative samples of employed and unemployed inhabitants of the biggest city in the country, pharmacists, prisoners and a sample of highly successful individuals, students of psychology and students of other major subjects. Validity was tested also as internal consistency, using Cronbach alpha coefficients, which are mostly very satisfactory. Reliability was verified with the following techniques: correlation between forms, Spearman-Brown (un)equal lengths, Split half (Guttmann), Alpha coefficient. Most coefficients were between 0.80 and 0.90 . Sensibility was identified as the relation between the certain measure of central tendency and measure of dispersion: in our case, as the relation between mean and amplitude of responses. Almost all instruments, applied in the presented research, were previously applied in other studies in non-clinical populations, and their distributions tested with Kolmogorov Smirnov test did not differ $(p>0.05)$ or differed only slightly $(0.04<p<0.05)$.

After the baseline data collection, the questionnaires were applied in the years 5, 10 and 18 of the follow-up.
The last data collection was completed by 32 subjects (26 males, 6 females) in 2010. Roughly about one sixth of the original sample died (34 subjects) and were thus lost to follow-up, and another sixth did not return the questionnaires. The flowchart of the sample is shown in Figure 1.

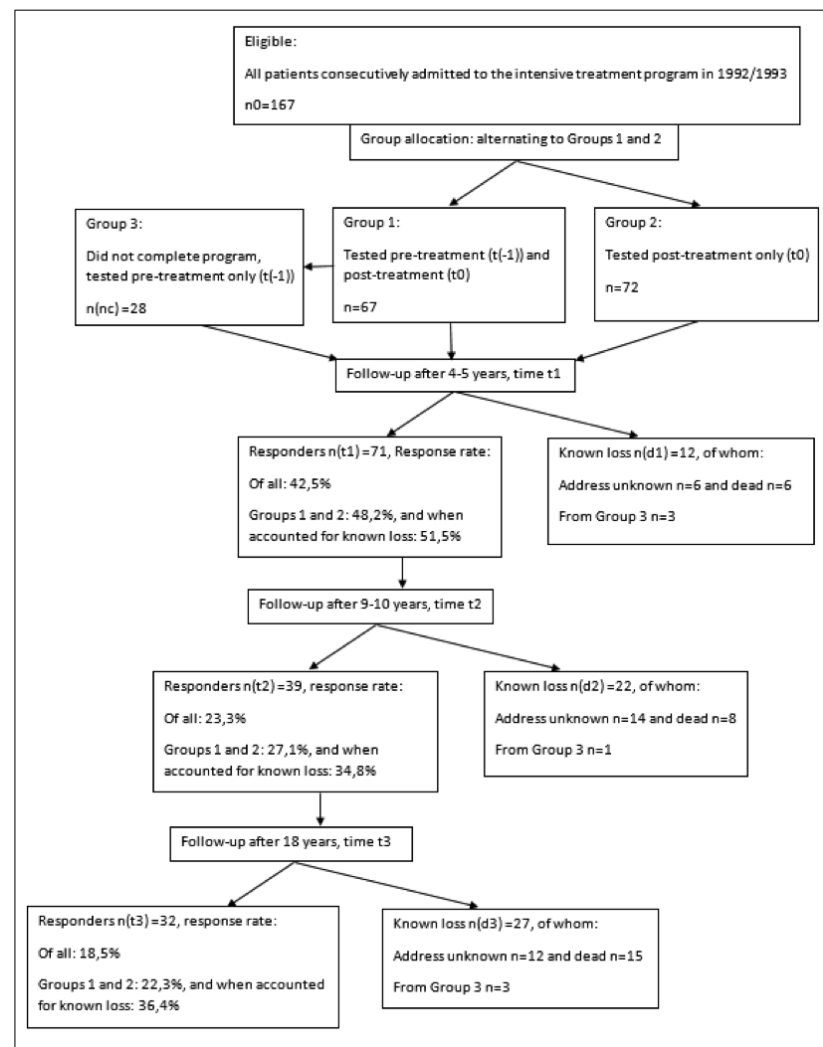

Figure 1. Study flow chart: Patients' inclusion and dropout from the study.

Among a variety of data collected were demographic variables, treatment process-related variables, cooccurring medical and mental disorders, abstinence status, lifestyle and the information on the following constructs from the modified TPB: perceived needs satisfaction (NS), normative differential (ND), perceived alcohol utility (UT), beliefs about treatment programme benefits $(\mathrm{BE})$ and behavioural intentions $(\mathrm{BI})$. The scales were recoded to reflect abstinence-oriented direction (the higher the score, more pro-abstinent behaviour), except for UT (the higher the score, the higher the importance/ attractiveness of alcohol).

The study subjects are representatives of the clinical population with the syndrome of alcohol dependence. Their co-occurring diseases status did not affect their abstinence during the follow-up period. The same is described in the article by Rus-Makovec and Čebašek-Travnik in 2008 (21). The longitudinal nature of the study has the advantage 
of every subject being a control to oneself, which in turn controls for a variety of covariates. Similarly, the model constructs themselves include cognitive and emotional processes, which serve as both background factors and modifiers of behavioural, normative and control beliefs (22), thus, in consequence, serving as both behavioural indicators and control variables of a variety of influences within and between subjects.

The analytical sample of the presented results is comprised of subjects who participated in the followups. For the between-groups analysis there were 64, 64, 26 and 21 valid cases in time points at the end of the treatment programme, and 5, 10 and 18 years of followup, respectively. The within-subject analysis used 16 valid cases with full information from all follow-up points after the completion of the treatment.

Statistical analyses followed a standard explore-analyseexplore approach. The type I error limit was set at 0.05 and models were corrected for multiple analyses using Bonferroni method. This paper presents the results on the relationship between follow-up periods (i.e. time after intensive treatment) and summative scores of variables measuring individual mTPB constructs, all measured scales having satisfactory measuring characteristics (23). We applied the multivariate analysis of variance. The analyses were performed by SPSS 23 for Windows.

\section{RESULTS}

\subsection{Between-Group Analysis}

The model had acceptable characteristics with Wilks' Lambda 0.015 and exact $F(5,167)=2176.041$ at $p<0.001$. Table 1 shows means of all indicators across time points. The higher mean reflects more pro-abstinent-oriented direction of NS, ND, BE and BI. Lower UT score reflects decrease in perception of alcohol importance. BI remained stable at the same level as at the end of treatment programme, whereas BE and UT robustly changed in proabstinence direction over time and levelled off after 10 years of follow-up. NS and ND showed the same orientation of change and levelled off after 10 years of follow-up, although the trend was not significant.

\subsection{Within-Subject Analysis}

A repeated measures ANOVA with a Greenhouse-Geisser correction revealed robust significant differences over time in UT and BE, marginal difference in NS, and differences in ND and $\mathrm{BI}$ as not significant. Details are listed in Table 2.
Table 1. Estimated means of mTPB indicators - between-level analysis of variance.

\begin{tabular}{|c|c|c|c|c|}
\hline \multirow{2}{*}{$\begin{array}{l}\text { Indicator } \\
\text { and time point }\end{array}$} & \multirow[b]{2}{*}{ Mean } & \multirow[b]{2}{*}{ SE } & \multicolumn{2}{|c|}{$95 \% \mathrm{Cl}$} \\
\hline & & & $\mathbf{L}$ & U \\
\hline \multicolumn{5}{|l|}{ NS } \\
\hline End of treatment & 66.5 & 1.68 & 63.2 & 69.8 \\
\hline 5-year follow-up & 62.7 & 1.68 & 59.4 & 66.0 \\
\hline 10-year follow-up & 60.7 & 2.63 & 55.5 & 65.9 \\
\hline 18-year follow-up & 61.0 & 2.93 & 55.2 & 66.7 \\
\hline \multicolumn{5}{|l|}{ ND } \\
\hline End of treatment & 47.2 & 1.38 & 44.4 & 49.9 \\
\hline 5-year follow-up & 45.4 & 1.38 & 42.7 & 48.1 \\
\hline 10-year follow-up & 49.7 & 2.16 & 45.4 & 54.0 \\
\hline 18-year follow-up & 50.2 & 2.40 & 45.5 & 55.0 \\
\hline \multicolumn{5}{|l|}{ UT } \\
\hline End of treatment & 42.2 & 2.14 & 37.9 & 46.4 \\
\hline 5-year follow-up & 30.5 & 2.14 & 26.3 & 34.7 \\
\hline 10-year follow-up & 26.8 & 3.36 & 20.1 & 33.4 \\
\hline 18-year follow-up & 28.4 & 3.74 & 21.0 & 35.8 \\
\hline \multicolumn{5}{|l|}{ BE } \\
\hline End of treatment & 48.4 & 1.11 & 46.2 & 50.6 \\
\hline 5-year follow-up & 48.4 & 1.11 & 46.2 & 50.6 \\
\hline 10-year follow-up & 63.7 & 1.75 & 60.2 & 67.1 \\
\hline 18-year follow-up & 59.3 & 1.94 & 55.4 & 63.1 \\
\hline \multicolumn{5}{|l|}{ BI } \\
\hline End of treatment & 8.6 & 0.53 & 7.5 & 9.6 \\
\hline 5-year follow-up & 8.6 & 0.53 & 7.5 & 9.6 \\
\hline 10-year follow-up & 9.1 & 0.83 & 7.5 & 10.7 \\
\hline 18-year follow-up & 8.1 & 0.92 & 6.3 & 9.9 \\
\hline
\end{tabular}

Note: NS - needs satisfaction, ND - normative differential, UT alcohol utility, BE - beliefs about treatment program benefits, $\mathrm{BI}$ behavioral intentions, $\mathrm{SE}$ - standard error, $\mathrm{Cl}$ - confidence interval, L - Cl's lower bound, U - Cl's upper bound

Table 2. Within-subject model characteristics - GreenhouseGeisser correction of repeated measures ANOVA.

\begin{tabular}{lccccc}
\hline Indicator & $\mathrm{df}$ & $\mathrm{df}$ (error) & Exact $\mathrm{F}$ & $\mathrm{p}$-value & Eta2 \\
\hline NS & 2.508 & 37.615 & 2.882 & 0.057 & 0.161 \\
ND & 2.813 & 42.192 & 0.593 & 0.612 & 0.038 \\
UT & 1.986 & 29.790 & 3.819 & 0.034 & 0.203 \\
BE & 1.921 & 28.820 & 15.938 & $<0.001$ & 0.515 \\
BI & 1.894 & 28.405 & 0.385 & 0.673 & 0.025 \\
\hline
\end{tabular}

Note: NS - needs satisfaction, ND - normative differential, UT alcohol utility, BE - beliefs about treatment program benefits, BI - behavioral intentions, Eta2 - partial eta squared, df - indicator's degrees of freedom, df (error) - indicator standard error's degrees of freedom 
Table 3. Significant and marginally significant pairwise comparisons of within-subject differences - repeated measures ANOVA.

\begin{tabular}{lcccccc}
\hline Indicator & Difference & $\begin{array}{c}\text { Mean } \\
\text { Difference }\end{array}$ & Std. Error & p-value & \multicolumn{2}{c}{$95 \% \mathrm{Cl}$} \\
\cline { 5 - 7 } & & & & 0.051 & -25.901 & 0.026 \\
UT & $3-1$ & -12.938 & 4.270 & 0.052 & -23.449 & 0.074 \\
BE & $4-1$ & -11.688 & 3.874 & 0.001 & 6.203 & 24.297 \\
& $3-1$ & 15.250 & 2.980 & 0.005 & 3.088 & 19.662 \\
& $4-1$ & 11.375 & 2.729 & 0.001 & 3.203 & 24.297 \\
& $3-2$ & 15.250 & 2.980 & 0.005 & 3.088 & 19.662 \\
\hline
\end{tabular}

Note: Difference is the difference between estimates from different time points: 1 - the end of treatment program, 2 - after 5 years, 3 - after 10 years, 4 - after 18 years; UT - alcohol utility, BE - beliefs about treatment program benefits, $\mathrm{Cl}$ - confidence interval, L - Cl's lower bound, $\mathrm{U}$ - Cl's upper bound

Post hoc tests using the Bonferroni correction revealed UT and BE stabilise after 10 years of follow-up. Other pairwise comparisons reflected a similar trend, although they were not statistically significant. Table 3 shows detailed results of significant analyses.

Temporal profiles of all indicators are presented in Figure 2 (between-group) and Figure 3 (within-subject). The shape of the profiles is similar on both levels of the analysis, except for ND. On the within-subject level, ND increases slightly in the first five years after the treatment programme, then decreases slightly and stabilises. This is not statistically significant.

\section{DISCUSSION}

Presented results are unadjusted, because the inclusion of demographic variables did neither improve nor worsen the models. Findings reflect the stability of individual constructs over time, supporting life-long change. This, in turn, supports the sustainability of abstinence and, hence, healthier lifestyle relatively unburdened by the addiction and its consequences.

NS increases after 5 years, meaning that the perception (and self-evaluation) of needs satisfaction is continuously improving with abstinence immediately after the intensive treatment, then decreases and finally levels off. The longer the period of satisfying life (unburdened by addiction) is, the stronger is the experience of beneficial effects of the treatment, as seen in the increase of $B E$ means.

Our results show that short-term (within the first 5 years after the treatment) evaluations of patients' functioning and treatment programme effectiveness might have limited value, as some of more complex changes in selfperception take longer to be observed. This has both clinical and public health relevance, especially in the

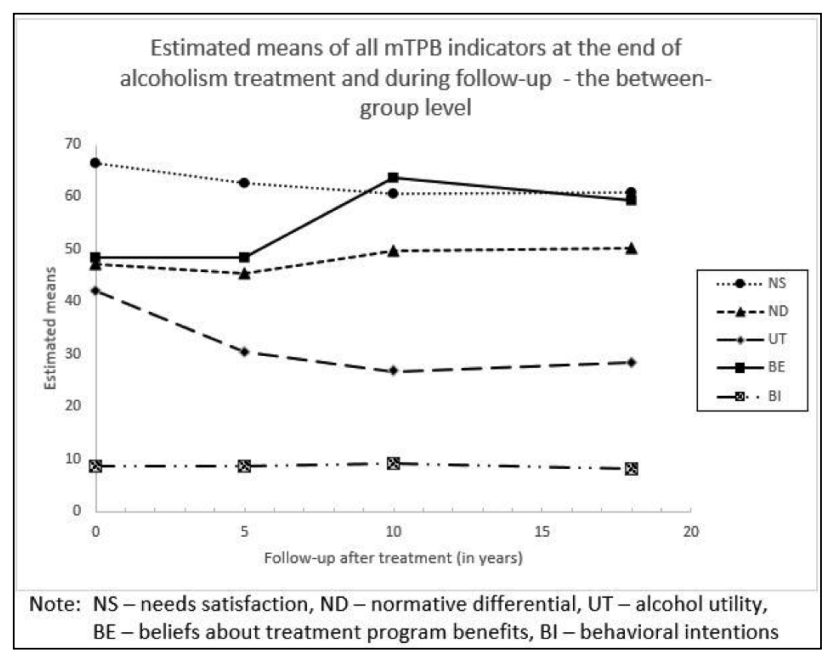

Figure 2. Estimated means of mTPB indicators - the betweengroups level.

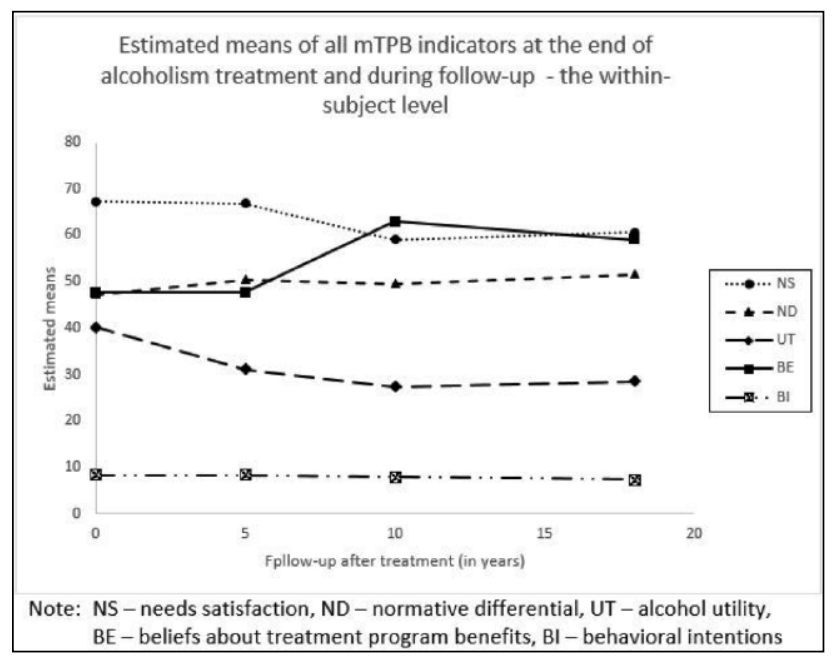

Figure 3. Estimated means of mTPB indicators - the withinsubject level. 
context of a country with a 'wet culture', which Slovenia is. World Health Organization's Burden of diseases project predicted that the syndrome of alcohol dependence will be the fourth among diseases with the highest burden for society by 2030 (24). It is estimated to cause $8 \%$ of the total burden of diseases in Europe (25), and roughly 8-10\% of adult population fulfil criteria for the syndrome of alcohol dependence in Slovenia (26). Clinical concerns should be recognised with respect to hazardous and harmful drinking as a pre-condition to alcohol dependence throughout the life span: binge drinking represents a rising problem in European young adults (27), and higher alcohol consumptions in later life is correlated with greater mental vulnerability (28). Hence, being able to understand predictive factors for a long-term proabstinence behaviour is of vital importance.

This longitudinal study was born as an interdisciplinary theory based project, including aspects from psychiatry, social psychology, sociology and communication studies. In the initial phases (pilot and preliminary quasiexperimental studies), the instruments were developed with mostly satisfactory measurement characteristics, especially evaluated at the levels of construct and external validity (22). The strengths of such a research approach are the longitudinal design, a representative sample of the Slovenian clinical population and the use of standardised instruments. A model-driven study is both a strength of the design and its limitation. The latter is minimalised by the key characteristic of TPB, that is, its adaptability and the potential for modifications. Other limitations include the drop of response level rates over time and a relatively high proportion of loss to followup due to death of study subjects ( 1 in 6 of the original sample) - and, hence, the number of valid cases also drops.

Notwithstanding the stated difficulties, our study offers evidence that perceived needs satisfaction (as part of self-concept) and beliefs about addiction treatment benefits play a crucial role in health-oriented behavioural and lifestyle changes over time. Previous research used a variety of operationalisations of the relation to self. In their condom use study, Aronson and colleagues (29) were among the first to show that one of the more effective ways to change behaviour is changing the interpretation of self (the attitudes about self, self-perceptions). Their results supported the hypothesis that the improvement in self-respect served as one of the determinants of the later behavioural change. A body of research in recent years revealed that the change in self-perception towards the self-image of a person whose history included addiction, but the latter was no longer a qualifier of the present lifestyle, is an important contributor to a lifestyle no longer burdened by addiction(e.g. 30, 31). Proabstinence-oriented indicator scores over time give rise to a possible interpretation that these results contribute to the ability of treated patients with alcohol dependence syndrome to regulate their mood and mental health at large via more positive affect and, hence, to be able to feel rewards from non-addictive behaviours (e.g. 32, 33). On the other hand, the importance of treatment benefits as experienced and evaluated by patients during the follow-up period improved over time, which reflects the usefulness of learned skills. In combination with improved self-perception, the two contribute to the long-term motivation for sustaining pro-abstinence lifestyle.

\section{CONCLUSIONS}

Theory-based research is feasible with longitudinal design in alcoholism treatment outcome research. Further research is also needed to explain the connection of clinically relevant theory-based constructs with the regeneration of mesolimbic structures.

\section{ACKNOWLEDGMENTS}

We thank prof. Velko S. Rus for all the support and valuable advice regarding methodology and analyses in this study.

\section{CONFLICTS OF INTEREST}

The authors declare that no conflicts of interest exist.

\section{FUNDING}

The study was financed by internal institutional sources.

\section{ETHICAL APPROVAL}

The research was approved by the Republic of Slovenia National Medical Ethics Committee, reference number $131 / 08 / 11$, and it conforms to the provisions of the Declaration of Helsinki in 1995 (as revised in Edinburgh in 2000).

\section{REFERENCES}

1. Ajzen I, Fishbein M. Attitudinal and normative variables as predictors of specific behaviors. J Pers Soc Psychol. 1973;27:41-57.

2. Fishbein $M$, Ajzen I. Attitudes toward objects as predictors of single and multiple behavior criteria. Psychol Rev. 1974;81:59-74.

3. Cialdini RB, Petty RE, Cacioppo JT. Attitude and attitude change. Ann Rev Psychol. 1981;32:357-404.

4. Visnovič Poredoš A, Kolšek M. The drinking habits of users of an alcohol drinking screening website in Slovenia. Zdr Varst. 2016;55:3642. doi: 10.1515/sjph-2016-0006. 
5. Nacionalni inštitut za javno zdravje. Registrirana poraba čistega alkohola pri odraslih prebivalcih $(15+$ let $)$, Slovenija, letno: podatkovni portal. Available 14 October 2017 from: https://podatki. nijz.si/pxweb/sl/NIJZ podatkovni portal/NIJZ podatkovni portal_4 Determinante zdravja_4bAlkohol/Alkohol.px/?rxid=47a6ea79-24204e9b-9917-77d6d42cc494

6. Ajzen I. The theory of planned behavior. Organ Behav Hum Decis Process. 1991;50:179-211.

7. McLellan AT, O Brien CP, Lewis DL, Kleber HD. Drug addiction as a chronic medical illness: implications for treatment, insurance and evaluation. JAMA. 2000;248:1689-95.

8. Ries RK, Miller SC, Fiellin DA, Saitz RS. Principles of addiction medicine. Philadelphia, PA: Lippincott Williams \& Wilkins, Wolters Kluwer, 2009.

9. Simpson DD, Joe GW, Brown BS. Treatment retention and followup outcomes in the drug abuse treatment outcome study (DATOS). Psychol Addict Behav. 1997;11:294-301. doi: 10.1037\%2F0893164X.11.4.294.

10. Nilssen 0 . Long-term effect of brief intervention in at-risk alcohol drinkers: 9-year follow-up study. Alcohol Alcohol. 2004;39:548-51. doi: 10.1093/alcalc/agh095.

11. Timko C, Moos RH, Finney JW, Connell EG. Gender differences in help - utilization and the 8-year course of alcohol abuse. Addiction. 2002;97:877-89. doi: 10.1046/j.1360-0443.2002.00099.x.

12. Greenfield L, Burgdorf K, Chen X, Porowski A, Roberts T, Herrell J. Effectiveness of long-term residential substance abuse treatment for women: findings from three national studies. Am J Drug Alcohol Abuse. 2004;30:537-50. doi: 10.1081/ADA-200032290.

13. Trim RS, Schuckit MA, Smith TL. Predictors of initial and sustained remission from alcohol use disorders: findings from the 30-year follow-up of the San Diego prospective study. Alcohol Clin Exp Res. 2013;37:1424-31. doi: 10.1111/acer.12107.

14. Vaillant GE, Clark W, Cyrus C, Milofsky ES, Kopp J, Wells Wulsin $\mathrm{V}$, et al. Prospective study of alcoholism treatment. Am J Med. 1983;75:455-63.

15. NIDA. Principles of drug dddiction treatment: a research-based guide. 3rd ed. National Institute on Drug Abuse website, 2012. Available 12 September 2017 from: https://www.drugabuse.gov/ publications/principles-drug-addiction-treatment-research-basedguide-third-edition.

16. Cortes Tomas M. A 1st application of the theory of planned behavior to explain the abandonment of treatment by dependent alcoholics. Rev Psicol Gen Apl. 2001;54:389-405.

17. McLellan AT, Weisner C. Achieving the public health and safety potential of subtsance abuse treatments: implications for patient referral, treatment »matching « and outcome evaluation. In: Bickel WK, DeGrandpre RJ, editors. Drug policy and human nature. Boston, MA: Springer, 1996: 127-54.

18. Ajzen I. Attitude structure and behavior. In: Pratkanis AR, Breckler SJ, Greenwald AG, editors. Attitude structure and function. Hillsdale, New Jersey: Erlbaum, 1989: 241-74.
19. Bandura A. Self-efficacy: toward a unifying theory of behavioral change. Psychol Rev. 1977;84:191-215.

20. Rus VS, Rus-Makovec M. Influence of the therapeutical work on the attitudes toward self and on different aspects of alcohol (ab)use. In: III European congress of psychology, July 4-9, 1993 Tampere, Finland. Abstracts. Helsinki: The Psychological Society, 1993: 568.

21. Rus-Makovec M, Čebašek-Travnik Z. Co-occurring mental and somatic diagnoses of alcohol dependent patients in relation to long-term aftercare alcohol abstinence and well-being. Psychiatr Danub. 2008;20:194-207.

22. Ajzen I. The theory of planned behaviour: reactions and reflections. Psychol Health. 2011;26:1113-27. doi: 10.1080/08870446.2011.613995.

23. Rus-Makovec M. Analysis of therapeuthical effects by treatement of patients with syndrom of the alcohol dependency: doctoral thesis. Ljubljana: University of Ljubljana, Medical Faculty, 1994.

24. Mathers CD, Loncar D. Projections of global mortality and burden of disease from 2002 to 2030. PLoS Med. 2006;3:e442. doi: 10.1371/ journal.pmed.0030442.

25. Anderson P, Baumberg P. Alcohol in Europe. London: Institute of Alcohol Studies, 2006.

26. Zaletel-Kragelj L, Čebašek-Travnik Z, Hovnik Keršmanc M. Čezmerno pitje alkoholnih pijač. In: Zaletel Kragelj L, Fras Z, Maučec Zakotnik $\mathrm{J}$, editors. Tvegana vedenja, povezana $\mathrm{z}$ zdravjem in nekatera zdravstvena stanja pri odraslih prebivalcih Slovenije: rezultati raziskave Dejavniki tveganja za nenalezljive bolezni pri odraslih prebivalcih Slovenije (z zdravjem povezan vedenjski slog). Ljubljana: CINDI Slovenija, 2004: 341-84.

27. Nasui BA, Popa M, Popescu CA. Drinking patterns and behavioral consequences: a cross-sectional study among Romanian university students. Zdr Varst. 2016;55:59-66. doi: 10.1515/sjph-2016-0009.

28. Stanojević-Jerković $O$, Kolšek $M$, Rotar Pavlič $D$. Indicators of problem drinking in the Slovenian elderly: a qualitative analysis. Zdr Varst. 2011;50:249-58. doi: 10.2478/v10152-011-0004-6.

29. Aronson E, Fried C, Stone J. Overcoming denial and increasing the intention to use condoms through the induction of hypocrisy. Am J Public Health. 1991;81:1636-8.

30. Shaw EH. An exploration of the process of recovery from heroin dependence: doctoral thesis. Hull: University of Hull, 2011.

31. Dunlop WL, Tracy JL. The autobiography of addiction: autobiographical reasoning and psychological adjustment in abstinent alcoholics. Memory. 2013;21:64-78. doi: 10.1080/09658211.2012.713970.

32. Cheetham A, Allen NB, Yücel M, Lubman DI. The role of affective dysregulation in drug addiction. Clin Psychol Rev. 2010;30:621-34. doi: 10.1016/j.cpr.2010.04.005.

33. Frings D, Albery IP. The social identity model of cessation maintenance: formulation and initial evidence. Addict Behav. 2015;44:35-42. doi: 10.1016/j.addbeh.2014.10.023. 